\title{
In vitro bulb formation of direct and indirect regeneration of Lilium orientalis cv. "Starfighter" plants
}

\author{
Nora M. Youssef ${ }^{1 *}$, Shimaa A. Shaaban², Zenna Fawzia Ghareeb ${ }^{3}$ and Lobna S. Taha ${ }^{1}$
}

\begin{abstract}
Background: Lily is one of the most important commercial cut flower species and one of the three major bulb crops in the commercial market. The aim was to assess and establish a suitable protocol for increasing the number of Lilium bulblets and enlarge their size.

Methodology: Different plant growth regulators (TDZ, 2,4-D, 2ip, and picloram) at different concentrations for direct and indirect micropropagation were used. Also, the effect of various concentrations of sucrose alone or with growth inhibitor on bulblet formation during three repeated subcultures was examined with anatomical study.

Results: For direct shoot organogenesis, culturing leaf explant on MS culture medium containing TDZ $(0.5 \mathrm{mg} / \mathrm{l})+$ 2,4-D (10 mg/l) led to the highest number of shootlets after 1 month. For indirect micropropagation, MS was supplemented with 2ip $(0.5 \mathrm{mg} / \mathrm{l})+$ picloram $(5 \mathrm{mg} / \mathrm{l})$-induced callus tissues which were differentiated to embryos then weak shoots after 3 months. For more proliferation, the highest numbers of shootlets, leaves, and bulb scales were observed on MS culture medium supplemented with $1.0 \mathrm{mg} / \mathrm{l}$ of BA plus $0.2 \mathrm{mg} / \mathrm{l} \mathrm{NAA}$. Using $60 \mathrm{~g} / \mathrm{l}$ of sucrose plus 3 or $6 \mathrm{mg} / \mathrm{l}$ of paclobutrazol led to the highest number of bulblets/explant for the third subculture. The highest bulblet diameters were recorded with $120 \mathrm{~g} / \mathrm{l}$ sucrose plus 6 or $3 \mathrm{mg} / \mathrm{l}$ paclobutrazol.

Conclusion: This study had reached to optimize a suitable protocol for direct and indirect micropropagation of Lilium orientalis cv. "Starfighter" bulbs and increase the number and size of bulbs that can be beneficial for increasing the production and reduce their price. This study will help the producers for commercial purposes.
\end{abstract}

Keywords: Lilium, Micropropagation, Bulblet formation and anatomy

\section{Background}

Lily plant is one of the most important commercial cut flower species and one of the three major bulb crops in the commercial market because of its large size and colorful and fascinating flowers (Robinson and Firoozabady 1993). It is an attractive economic flowering plant used as cut flowers or grown in pots (Pobudkiewicz and Treder 2006; Younis et al. 2014). Lily is a member of the genus Lilium, grouped in seven sections, consist of $100-$ 115 species, and can be planted under various climatic zones. Oriental lilies belonging to the Archelirion section are the most expensive among different lily forms due to

\footnotetext{
* Correspondence: norayousif20@yahoo.com

'Ornamental Plants and Woody Trees Dept., National Research Centre, P.O.

Box 12622, Dokki, Giza, Egypt

Full list of author information is available at the end of the article
}

their bulbs being highly valuable and their production requiring a special technique. Their hybrids are one of the most economical important groups with flowers which have a wide range of size, shape, color, and other morphological characteristics (Kumar et al. 2006; Roh 2011; Younis et al. 2014).

In vitro protocol produced fast mass production and speedy regeneration of uniform plant material and so has been recognized as a necessity particularly for future breeding and commercial utilization of the lily species (Pelkonen 2005; Muhanmmad et al. 2013). Tissue culture techniques are used for fast propagation of some species of the genus Lilium as oriental hybrid (Lian et al. 2002) and Lilium asiatic hybrid (Lian et al. 2003; Taha et al. 2018). In vitro scale culture is one of the best 
prolific vegetative propagation methods for lilies (Bahr and Compton 2004).

In vitro adventitious bud regeneration from scales of Lilium rely on many factors like cytokinin and auxin concentrations such as BA and NAA and sucrose concentration (Varshney et al. 2000; Kumar et al. 2005). Many previous studies found that bulblet growth was favorable when using a high concentration of sucrose in the growth medium (Joshi and Dhar 2009; Bakhshaie et al. 2010).

Plant growth retardants especially inhibitors of gibberellin biosynthesis are known by reducing the shoot length due to the shortening of plant internodes without changing their developmental patterns or being phytotoxic. Besides, they also reduce leaf size, enhance chlorophyll content, and cause thickening of roots (Smith et al. 1990). Paclobutrazol decreases stem elongation in various ornamental species (Coulston and Shearing 1985) and promotes storage organ development (Ziv 1989) when grown in media enriched with sucrose.

The present investigation was conducted in order to optimize an in vitro propagation protocol and identifying the suitable concentration of paclobutrazol and sucrose for bulb production from bulb scales explants of oriental lily.

\section{Materials and methods}

The present work was conducted at tissue culture Technique Laboratory, Central Labs, Ornamental Plants and Woody Trees Department, Agricultural and Biological Research Division, National Research Centre (NRC), Tissue Culture \& Germplasm Conservation Research Lab., Horticulture Research Institute, Agricultural Research Center-Giza (ARC), and Agricultural Botany Department, Faculty of Agriculture, Cairo University, Egypt, during years the 2017 and 2018 to establish an efficient in vitro culture protocol for rapid micropropagation and bulblet formation of oriental lily "Starfighter."

\section{Explant source and surface sterilization}

The scales of bulbs of Lilium (5-7 cm in diameter) were collected from a commercial nursery and gently excised from the points of attachment and surface sterilized in ethanol 70\% (v/v) for $30 \mathrm{~s}$, rinsed in Clorox 15\% (sodium hypochlorite) for $7 \mathrm{~min}$, then washed with sterilized distilled water three times. The scales were sterilized in $2 \%$ $\mathrm{HgCl}_{2}$ (MC) solution (w/v) for $10 \mathrm{~min}$ and finally rinsed three times in sterile water.

\section{Culture medium}

The sterilized bulb scales explants were cultured in jars containing $25 \mathrm{ml}$ MS free of hormones (Murashige and Skoog 1962) supplemented with 3\% sucrose and 0.7\% agar. The $\mathrm{pH}$ of the medium was adjusted to 5.6-5.8 then autoclaved at $121^{\circ} \mathrm{C}$ and $15 \mathrm{psi}$ for $15 \mathrm{~min}$.

\section{Incubation conditions}

The in vitro cultures during all stages were placed in the incubation room at $23 \pm 2{ }^{\circ} \mathrm{C}$ under $16 \mathrm{~h}$ photoperiod and $1.5 \mathrm{k}$ lux light intensity provided by cool, white, fluorescent lamps.

\section{Shoot organogenesis}

For direct and indirect shoots regeneration, the obtained leaves from culture starting were separated, sectioned, and transferred to MS medium supplemented with different plant growth regulators: $0.5 \mathrm{mg} / \mathrm{l}$ of thidiazuron (TDZ) and 6- $\gamma, \gamma$-dimethylallylamine purine riboside (2ip); 2,4-dichlorophenoxyacetic acid (2,4-D); and picloram at different concentrations (5 and $10 \mathrm{mg} / \mathrm{l}$ ) for in vitro shoot multiplication. The formed shoots were used as secondary explants for further in vitro shoots propagation.

\section{In vitro shoots proliferation}

For this stage, $0.5 \mathrm{mg} / \mathrm{l}$ of both 6-benzyl amino purine (BA) and thidiazuron (TDZ) in combination or separated with $\alpha$-naphthaleneacetic acid (NAA) at 0.1, 0.2, and $0.3 \mathrm{mg} / \mathrm{l}$ were tested. The characteristic features of regenerated plantlets were observed such as number of shootlets/explant, number of leaves/shootlet, and number of bulb scales/shootlet.

\section{Bulblet formation}

In this stage, shoot explants were transferred to culture media which contained different concentrations of sucrose $\left(30,60,90\right.$, and $\left.120 \mathrm{~g} \mathrm{~L}^{-1}\right)$ only or combined with growth inhibitors (3 and $6 \mathrm{mg} \mathrm{L}^{-1}$ paclobutrazol) for bulblet formation of Lilium through three subcultures as well as the diameter of the obtained bulblets.

\section{Hardening off}

The bulblets were removed from culture jars and transferred to pots containing peat moss + sand (1:1), covered with transparent polyethylene pages for 2 weeks and gradually removed in the greenhouse.

\section{Determination of total carbohydrates}

Fresh samples of bulblets were used to determine total carbohydrates as described by Dubois et al. (1956).

\section{Anatomical study}

Shootlets and different stages of somatic embryos were chosen from survived in vitro cultures (aged 12 weeks old) as well as the acclimatized bulbs that were aged 8 weeks after transferring to the greenhouse. Samples were fixed in F.A.A. (10 $\mathrm{ml}$ formalin, $5 \mathrm{ml}$ glacial acetic acid, 
and $85 \mathrm{ml}$ ethyl alcohol 70\%) and dehydrated in butyl alcohol series then embedded in paraffin wax of melting point $56{ }^{\circ} \mathrm{C}$. Sections $(20 \mu \mathrm{m})$ were cut with a rotary microtome. The sections were stained with crystal violet-erythrosine combination, cleared in xylene and mounted in Canada balsam (Willey 1971).

\section{Statistical analysis}

The average of recorded data for different parameters was statistically analyzed using randomized complete block design with ten replicates per treatment. LSD test at $5 \%$ for comparison among means was used according to methods of Steel and Torrie (1980).

\section{Results}

\section{Regenerative capacity}

The leaf explants of in vitro culture of oriental lily were introduced to MS medium supplemented with different plant growth regulators [thidiazuron (TDZ), 2,4-dichlorophenoxyacetic acid (2,4-D), 6- $\gamma, \gamma$-dimethylallylamine purine riboside (2ip), and picloram] at different concentrations for direct shoot regeneration from leaf explants or indirect regeneration from callus tissues (Table 1 and Fig. 1). For direct shoot organogenesis, culturing leaf explant on MS culture medium containing TDZ $(0.5 \mathrm{mg} /$ l) + 2,4-D $(10 \mathrm{mg} / \mathrm{l})$ was more effective and led to the highest number of shoots (5.7) after 1 month (Fig. 1a). MS supplemented with TDZ $(0.5 \mathrm{mg} / \mathrm{l})+2,4-\mathrm{D}(5 \mathrm{mg} / \mathrm{l})$ led to white friable calli, whereas using 2ip $(0.5 \mathrm{mg} / \mathrm{l})+$ picloram $(5 \mathrm{mg} / \mathrm{l})$ in the culture medium induced yellowish friable callus tissues. The development of callus tissues to differentiate embryos then weak shoots took 3 months. Different stages of somatic embryos that were inducted from callus were identified using the histological sections (Fig. 2).

Table 1 Effect of different concentrations of plant growth regulators on regenerative capacity of oriental lily leaf explant

\begin{tabular}{|c|c|c|c|}
\hline $\begin{array}{l}\text { Treatment } \\
(\mathrm{mg} / \mathrm{l})\end{array}$ & $\begin{array}{l}\text { Mean number } \\
\text { of regenerated } \\
\text { shoots }\end{array}$ & $\begin{array}{l}\text { Mean of } \\
\text { callus } \\
\text { frequency } \\
(\%)\end{array}$ & Morphogenesis \\
\hline $\begin{array}{l}\text { Control } \\
\text { (0.0 hormones) }\end{array}$ & 0 & 0 & - \\
\hline TDZ (0.5 mg/l) & 0 & 50.2 & White friable calli \\
\hline $\begin{array}{l}\text { TDZ }(0.5 \mathrm{mg} / \mathrm{l}) \\
+2,4-\mathrm{D}(5 \mathrm{mg} / \mathrm{l})\end{array}$ & 2.8 & 61.4 & $\begin{array}{l}\text { White friable calli + } \\
\text { regenerated shoots }\end{array}$ \\
\hline $\begin{array}{l}\text { TDZ (0.5 mg/l) } \\
+2,4-\mathrm{D}(10 \mathrm{mg} / \mathrm{l})\end{array}$ & 5.7 & 0 & $\begin{array}{l}\text { Direct regenerated } \\
\text { shoots }\end{array}$ \\
\hline $\begin{array}{l}\text { 2ip }(0.5 \mathrm{mg} / \mathrm{l})+ \\
\text { picloram }(5 \mathrm{mg} / \mathrm{l})\end{array}$ & 2.1 & 73 & $\begin{array}{l}\text { Yellowish friable calli } \\
+ \text { regenerated shoots }\end{array}$ \\
\hline $\begin{array}{l}\text { 2ip }(0.5 \mathrm{mg} / \mathrm{l})+ \\
\text { picloram }(10 \mathrm{mg} / \mathrm{l})\end{array}$ & 0 & 0 & - \\
\hline
\end{tabular}

The anatomical study (Fig. 3) indicated the histological section of the control that showed the shootlet formation of lily plant consisting of apical meristem (SAM) end compassed with leaf primordial (lp) and young leaves (l). The axis of the shoot tip in these plant seems to be more wider but shorter than those of the embryogenesis. The formation of buds from bulb scales was observed after formation of calluses at the lower end. The plantlet resulted from the direct organogenesis which looked like a bulblet. Plantlets that were directly grown on culture medium containing TDZ $(0.5 \mathrm{mg} / \mathrm{l})+2,4-\mathrm{D}$ $(10 \mathrm{mg} / \mathrm{l})$ showed formation of many shoot apical meristems as compared to other treatments.

\section{In vitro shoot proliferation}

The different responses of regenerated shoot from explants that were cultured on MS culture medium supplemented with various concentrations of BA, TDZ (0.5, 1.0 , and $2.0 \mathrm{mg} / \mathrm{l}$ ) and NAA $(0.1,0.2$, and $0.3 \mathrm{mg} / \mathrm{l})$ to proliferate more shoots were reported in Table 2. The highest number of shootlets, leaves, and bulb scales $(8.25,5.44$, and 8.88 respectively) was observed in the MS medium supplemented with $1.0 \mathrm{mg} / \mathrm{l}$ of BA plus 0.2 mg/l NAA compared with the other treatments. The lowest number of shoots and bulb scales per explant (1.22 and 2.44, respectively) were recorded for MS free hormone (control) treatment.

\section{Bulblet formation}

Data presented in Table 3 show a comparison for the effect of different concentrations of sucrose $(30,60,90$, and $120 \mathrm{~g} / \mathrm{l}$ ) alone or combined with growth inhibitor (3 and $6 \mathrm{mg} / \mathrm{l}$ paclobutrazol) on bulblet formation of Lilium through three subcultures in MS media. Higher bulblet formation was recorded with increasing the concentration of sucrose alone at 90 and $120 \mathrm{~g} / \mathrm{l}$ (3.01 and 2.86, respectively). Also, sucrose at $60 \mathrm{~g} / \mathrm{l}$ with paclobutrazol at 3 and $6 \mathrm{mg} / \mathrm{l}$ significantly increased bulb formation (2.99 and 2.84, respectively) as compared to other treatments.

Concerning the effect of subculture number on bulblet formation, the results revealed that the increase in the number of the repeated subcultures lead to a significant increase in the bulblet formation. The third subculture produced the maximum bulblets formed (2.99 bulblets) in MS medium as compared to the first or second subcultures (1.39 and 2.36 bulblets, respectively).

The interaction effect of different concentrations of sucrose and paclobutrazol on the number of subcultures revealed that using $60 \mathrm{~g} / \mathrm{l}$ of sucrose plus 3 or $6 \mathrm{mg} / \mathrm{l}$ paclobutrazol led to the highest number of bulblets/explant (4.44 and 4.08 bulblets, respectively) for the third subculture. Also, the bulblet formation was significantly increased by adding sucrose at concentrations of 90 and 


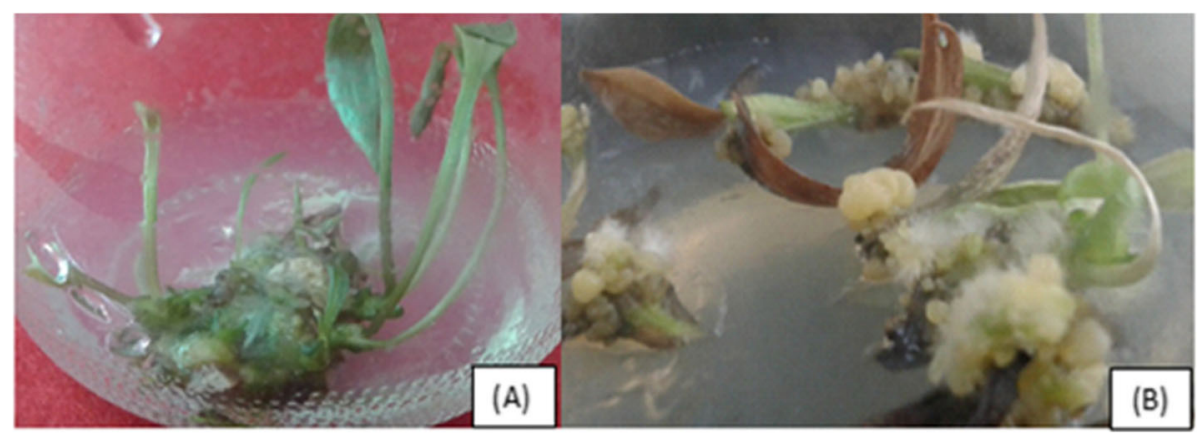

Fig. 1 Regenerative capacity of oriental lily affecting by different plant growth regulators. a Direct regenerated shoots on MS supplemented with $\operatorname{TDZ}(0.5 \mathrm{mg} / \mathrm{l})+2,4-\mathrm{D}(10 \mathrm{mg} / \mathrm{l})$ and $\mathbf{b}$ white friable calli on MS supplemented with TDZ $(0.5 \mathrm{mg} / \mathrm{l})+2,4-\mathrm{D}(5 \mathrm{mg} / \mathrm{l})$

$120 \mathrm{~g} / \mathrm{l}$ (3.78 and 3.89 bulblets, respectively) for third subculture, comparing with other treatments (Fig. 4).

\section{Bulblet diameter}

The higher concentration of sucrose with paclobutrazol concentrations was more effective on increasing diameter of bulblets (Fig. 5). The highest bulblet diameters were recorded with $120 \mathrm{~g} / \mathrm{l}$ sucrose plus 6 or $3 \mathrm{mg} / \mathrm{l}$ paclobutrazol (1.68 and $1.63 \mathrm{~cm}$, respectively) followed by $90 \mathrm{~g} / \mathrm{l}$ sucrose alone or plus $6 \mathrm{mg} / \mathrm{l}$ paclobutrazol (1.45 and $1.43 \mathrm{~cm}$, respectively) comparing with other treatments, whereas the lowest diameter of bulblets $(0.6$ $\mathrm{cm})$ was recorded with MS culture medium which contains $30 \mathrm{~g} / \mathrm{l}$ sucrose only.

\section{Total carbohydrate percentage}

The carbohydrate percentage was increased in the same treatment for bulblets' diameter enlarged. The highest percentage (41.01\%) was recorded with $120 \mathrm{~g} / \mathrm{l}$ sucrose plus 3 or $6 \mathrm{mg} / \mathrm{l}$ paclobutrazol comparing with other treatments (Fig. 6).

\section{The anatomical study}

The anatomical study on successful acclimatized survived plants (Fig. 7) confirmed the stimulation effect of $120 \mathrm{~g} / \mathrm{l}$ sucrose plus $6 \mathrm{mg} / \mathrm{l}$ paclobutrazol which produced the large size of bulbs as compared to those of the control.

\section{Discussion}

The present results of Fig. 2 were in agreement with the development of callus tissues to differentiate embryos; different stages of somatic embryos that were identified using the histological sections were described as small meristematic cells with regular shape, prominent nucleus, densely cytoplasm, and stained cell walls without

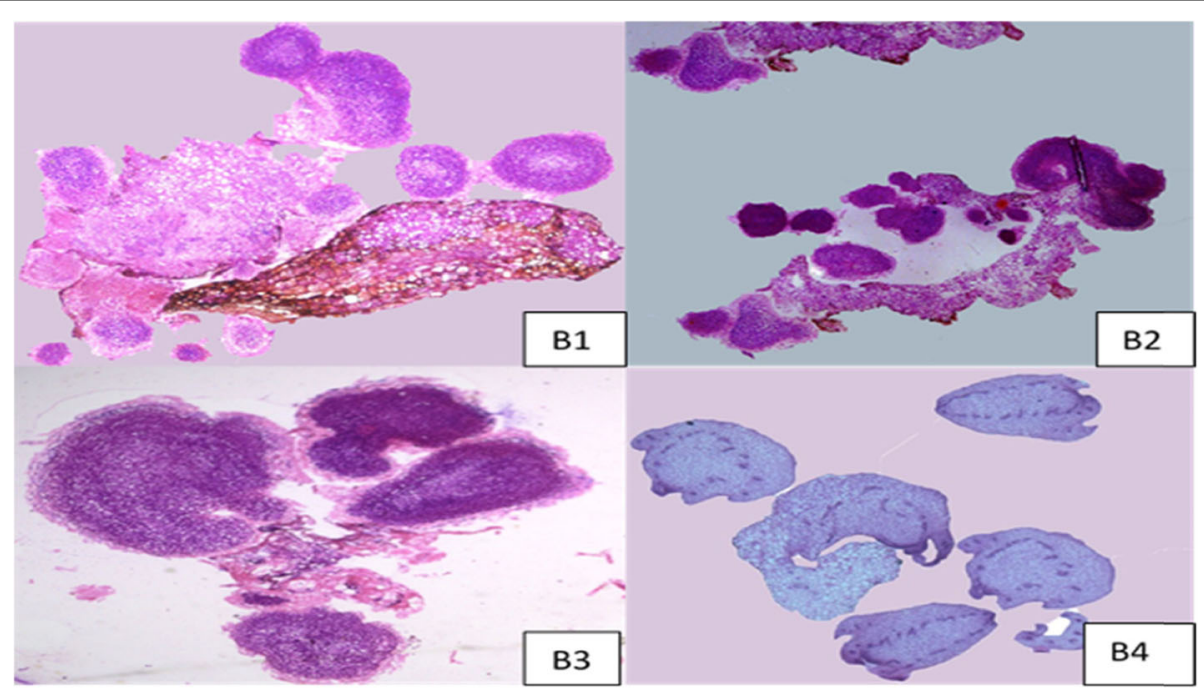

Fig. 2 Histological observation of different stages of somatic embryos. B1 Globular-shaped embryo. B2 Heart-shaped embryo. B3 Torpedoshaped embryo. B4 Primary embryos 


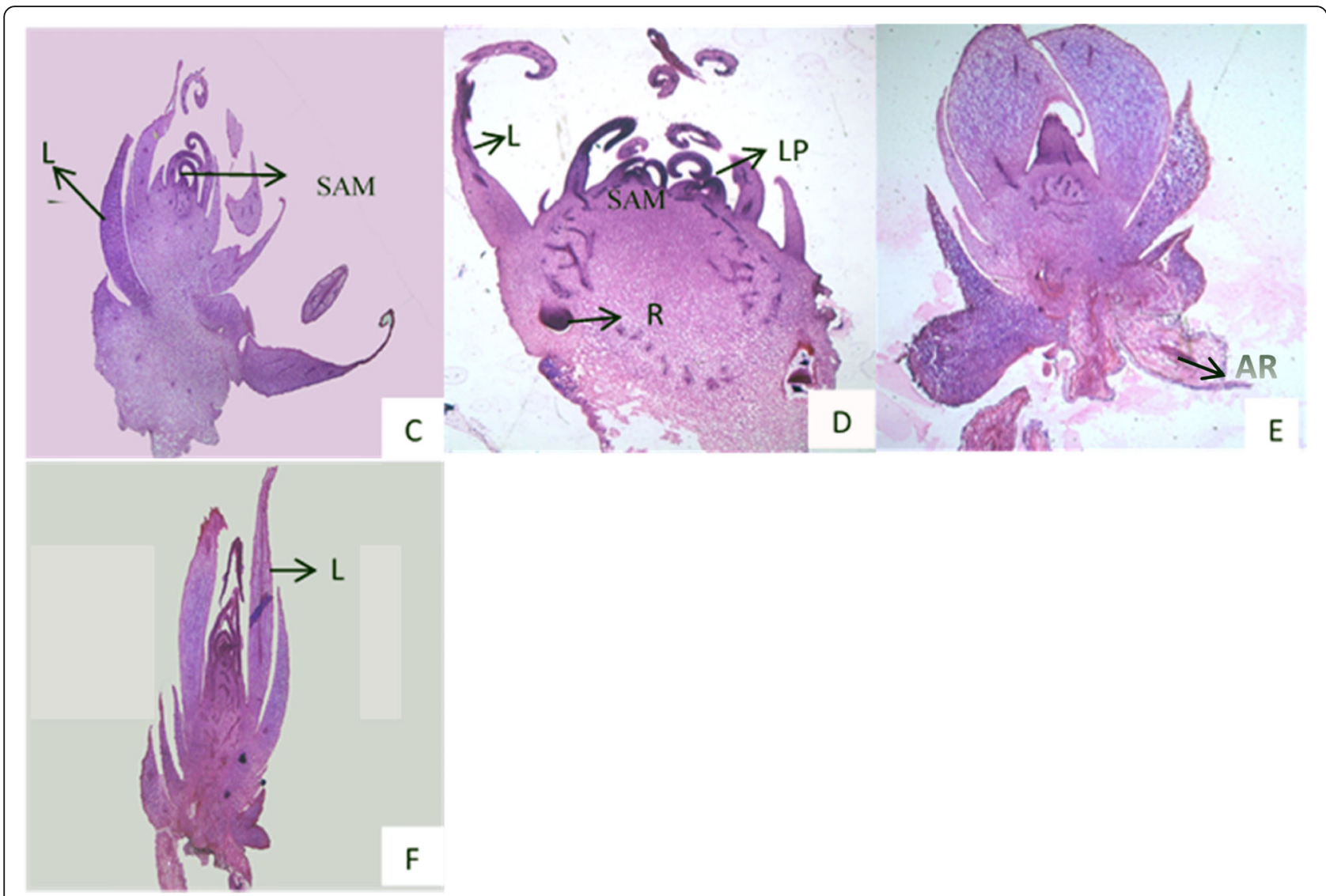

Fig. 3 c Longitudinal section on the plantlet produced on MS medium free of hormones. $\mathbf{d}$, e Longitudinal section on the plantlet grown on MS supplemented with TDZ $(0.5 \mathrm{mg} / \mathrm{l})+2,4-\mathrm{D}(10 \mathrm{mg} / \mathrm{l})$. $\mathbf{f}$ Longitudinal section on the plantlet grown on MS supplemented with TDZ $(0.5 \mathrm{mg} / \mathrm{l})+2,4-$ $D(5 \mathrm{mg} / \mathrm{l})$. R, root regeneration; $A R$, adventitious roots; $L P$, leaf primordium; L, leaf

intercellular space (Vinterhalter et al. 2016). The globular embryos were developed into heart shapes. The heart somatic embryos then transferred to torpedo stage as described by Dam and Bandyopadhyay (2010), which finally differentiated into a structure that seems like zygotic embryo of the plant.

Table 2 Effect of BA and TDZ combined with NAA at different concentrations on in vitro shoot proliferation of Lilium

\begin{tabular}{llll}
\hline Treatment (mg/l) & $\begin{array}{l}\text { Number of } \\
\text { shoots/explants }\end{array}$ & $\begin{array}{l}\text { Number of } \\
\text { leaves/shoots }\end{array}$ & $\begin{array}{l}\text { Number of } \\
\text { scales/explants }\end{array}$ \\
\hline $\begin{array}{l}\text { Control (MS free } \\
\text { hormones) }\end{array}$ & $1.22^{\mathrm{d}}$ & $2.59^{\mathrm{c}}$ & $2.44^{\mathrm{e}}$ \\
BA 0.5 + NAA 0.1 & $1.20^{\mathrm{d}}$ & $2.36^{\mathrm{c}, \mathrm{d}}$ & $2.83^{\mathrm{c}, \mathrm{d}}$ \\
BA 1.0 + NAA 0.2 & $8.25^{\mathrm{a}}$ & $5.44^{\mathrm{a}}$ & $8.88^{\mathrm{a}}$ \\
BA 2.0 + NAA 0.3 & $1.22^{\mathrm{d}}$ & $2.24^{\mathrm{c}, \mathrm{d}}$ & $2.25^{\mathrm{e}}$ \\
TDZ 0.5 + NAA 0.1 & $1.63^{\mathrm{c}}$ & $2.30^{\mathrm{c}, \mathrm{d}}$ & $2.50^{\mathrm{d}, \mathrm{e}}$ \\
TDZ 1.0 + NAA 0.2 & $6.00^{\mathrm{b}}$ & $4.91^{\mathrm{b}}$ & $5.99^{\mathrm{b}}$ \\
TDZ 2.0 + NAA 0.3 & $1.67^{\mathrm{c}}$ & $2.14^{\mathrm{d}}$ & $3.09^{\mathrm{c}}$ \\
LSD at 0.05 & 0.40 & 0.39 & 0.37 \\
\hline a-e within a column having the same letters are not significantly different at 5\% level
\end{tabular}

a-e within a column having the same letters are not significantly different at $5 \%$ level
It could be observed from this study that direct shoot regeneration was favored to obtain higher shoot frequency than those obtained from indirect one. The different responses of shoot regeneration varied in morphogenesis affected by growth regulators as mentioned by many studies, and both cytokinins and auxins were used for regeneration of lily bulblets, but the role of TDZ is known for both somatic embryogenesis induction and regeneration of shoots on the same explant (Huetteman and Preece 1993).

The data in Table 2 were in harmony with those obtained by Paek and Murthy (2002); they showed that auxin is effective for shoot promoting, and it is essential with a cytokinin for shoot induction.

For bulblet formation in Table 3, it was reported that the growth of bulblets depended on the sucrose concentration (Yamagishi 1998; Kumar et al. 2005), whereas the number of bulblets was higher by increasing the level of sucrose for oriental hybrid lily "Stargazer," and using paclobutrazol had stimulation effect on the number of bulblets compared with the control. Bulb formation of Lilium was significantly encouraged by the addition of 
Table 3 Bulblet formation of Lilium under effect of sucrose and paclobutrazol at various concentrations during three repeated subcultures

\begin{tabular}{|c|c|c|c|c|}
\hline Treatment & First subculture & Second subculture & Third subculture & Treatments means $(\mathrm{A})$ \\
\hline Control (sucrose $30 \mathrm{~g} / \mathrm{I}$ ) (S1) & 1.11 & 1.22 & 2.64 & $1.66^{c}$ \\
\hline Sucrose 60 g/l (S2) & 1.50 & 2.50 & 3.16 & $2.42^{\mathrm{b}}$ \\
\hline Sucrose $90 \mathrm{~g} / \mathrm{l}$ (S3) & 1.83 & 3.42 & 3.78 & $3.01^{\mathrm{a}}$ \\
\hline Sucrose $120 \mathrm{~g} / \mathrm{l}$ (S4) & 1.22 & 3.33 & 4.44 & $2.99^{\mathrm{a}}$ \\
\hline $\mathrm{S} 1+$ paclobutrazol $3 \mathrm{mg} / \mathrm{l}$ & 1.61 & 3.06 & 3.33 & $2.67^{\mathrm{a}, \mathrm{b}}$ \\
\hline $\mathrm{S} 2+$ paclobutrazol $3 \mathrm{mg} / \mathrm{l}$ & 1.39 & 3.31 & 3.89 & $2.86^{\mathrm{a}}$ \\
\hline S3+ paclobutrazol 3 mg/l & 1.22 & 1.44 & 2.89 & $1.85^{c}$ \\
\hline \$4+ paclobutrazol 3 mg/l & 1.11 & 1.37 & 2.11 & $1.53^{c, d}$ \\
\hline $\mathrm{S} 1+$ paclobutrazol $6 \mathrm{mg} / \mathrm{l}$ & 1.78 & 3.11 & 3.22 & $2.70^{a, b}$ \\
\hline $\mathrm{S} 2+$ paclobutrazol $6 \mathrm{mg} / \mathrm{l}$ & 1.89 & 2.56 & 4.08 & $2.84^{\mathrm{a}}$ \\
\hline S3+ paclobutrazol $6 \mathrm{mg} / \mathrm{l}$ & 1.11 & 1.17 & 1.33 & $1.20^{\mathrm{d}}$ \\
\hline \$4+ paclobutrazol $6 \mathrm{mg} / \mathrm{l}$ & 0.78 & 1.25 & 1.78 & $1.27^{d}$ \\
\hline Means of subculture (B) & $1.39^{c}$ & $2.36^{\mathrm{b}}$ & $2.99^{\mathrm{a}}$ & \\
\hline LSD at 0.05 & \multicolumn{4}{|c|}{ Treatment $(A)=0.33$, subculture $(B)=0.16, A \times B=0.57$} \\
\hline
\end{tabular}

${ }^{a-d}$ within a column having the same letters are not significantly different at $5 \%$ level

paclobutrazol (PBZ) even at lower concentrations (Thakur et al. 2006). Wang et al. (1999) found that using paclobutrazol produced better bulb formation for Lilium plantlets. Also, confirmed reports pointed out that the treatments with paclobutrazol led to a shift in the partitioning of assimilates from the leaves to the storage organs and roots and increased chlorophyll and carbohydrates in all parts of seedlings (Hazarika 2003).
From Fig. 5, it seemed that sucrose and paclobutrazol play an effective role in bulblets' diameter of oriental hybrid lily in vitro. Support findings from the studies of Langens-Gerrits et al. (2003) during in vitro culture observed that the high concentration of sucrose had the large bulblets. The increase in bulblets' size was obtained on the medium supplemented with high concentration of sucrose $(60$ and $90 \mathrm{~g} / \mathrm{l})$ in various Lilium

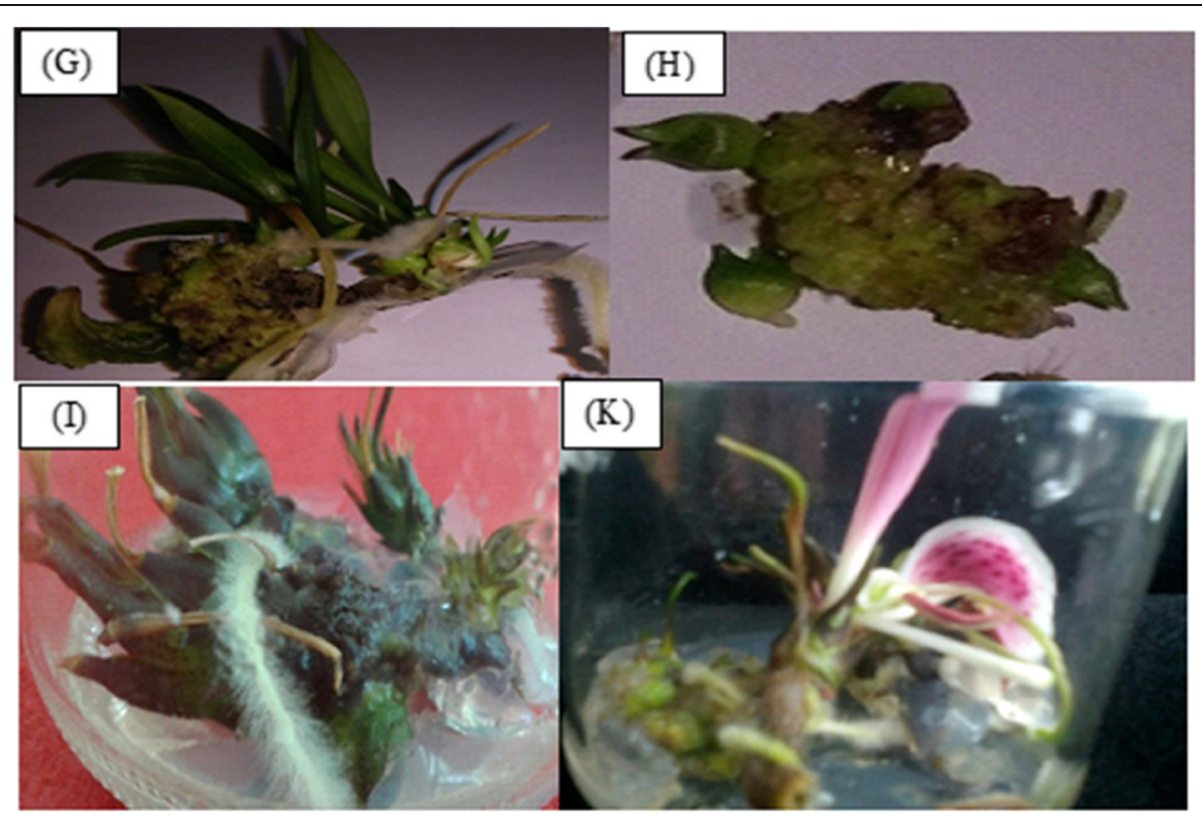

Fig. 4 Development of Lilium bulblets during three repeated subcultures. $\mathbf{g - i}$ In vitro proliferation of shootlets and bulblets during second subculture on MS culture medium supplemented with $120 \mathrm{~g} / \mathrm{l}$ sucrose. $\mathbf{k}$ In vitro flowering after 3 months on the same medium 


\section{Bulblet diameter}

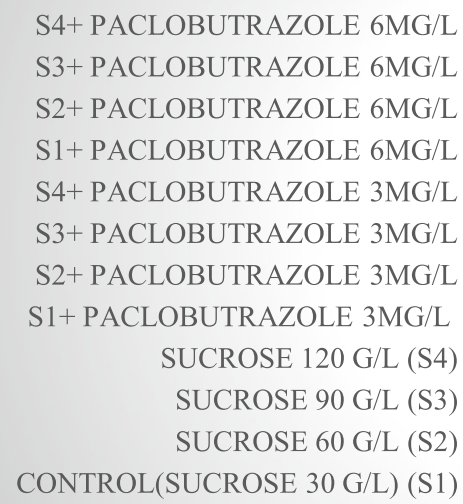

S4+ PACLOBUTRAZOLE 6MG/L

S3+ PACLOBUTRAZOLE 6MG/L

S2+ PACLOBUTRAZOLE 6MG/L

S1+ PACLOBUTRAZOLE 6MG/L

S4+ PACLOBUTRAZOLE 3MG/L

S3+ PACLOBUTRAZOLE 3MG/L

S2+ PACLOBUTRAZOLE 3MG/L

S1+ PACLOBUTRAZOLE 3MG/L

SUCROSE $120 \mathrm{G} / \mathrm{L}(\mathrm{S} 4)$

SUCROSE $90 \mathrm{G} / \mathrm{L}(\mathrm{S} 3)$

SUCROSE $60 \mathrm{G} / \mathrm{L}(\mathrm{S} 2)$

CONTROL(SUCROSE $30 \mathrm{G} / \mathrm{L}$ ) (S1)

Fig. 5 Bulblets' diameter of oriental hybrid lily as effected by different concentrations of sucrose and paclobutrazol

cultivars using different explants (Bonnier and Van 1997). The increase in bulblets' size in high level of sucrose was due to the raise in starch and total carbohydrates (Langens-Gerrits et al. 1997). The interaction effect of paclobutrazol and sucrose was significant for cormel size. Using $120 \mathrm{~g} / \mathrm{l}$ sucrose and $10 \mathrm{mg} / \mathrm{l}$ of paclobutrazol in MS culture medium gave the best formation of bigger cormels (Nagaraju et al. 2002). Moreover, paclobutrazol play an important role in enhancing the accumulation of soluble carbohydrates and starch (Wu et al. 2019).
This large size of acclimatized bulblets that appeared in the anatomical study as a result of using $120 \mathrm{~g} / \mathrm{l} \mathrm{su}$ crose plus $6 \mathrm{mg} / \mathrm{l}$ paclobutrazol in the culture medium might be attributed to the increase in size and number of scaly leaves which were affective on flower size of lily plant.

\section{Conclusion}

Lilium orientalis cv. "Starfighter" bulbs can be obtained by direct shoot organogenesis, culturing leaf explant on MS culture medium containing TDZ $(0.5 \mathrm{mg} / \mathrm{l})+2,4-\mathrm{D}$

\section{Carbohydrates\%}

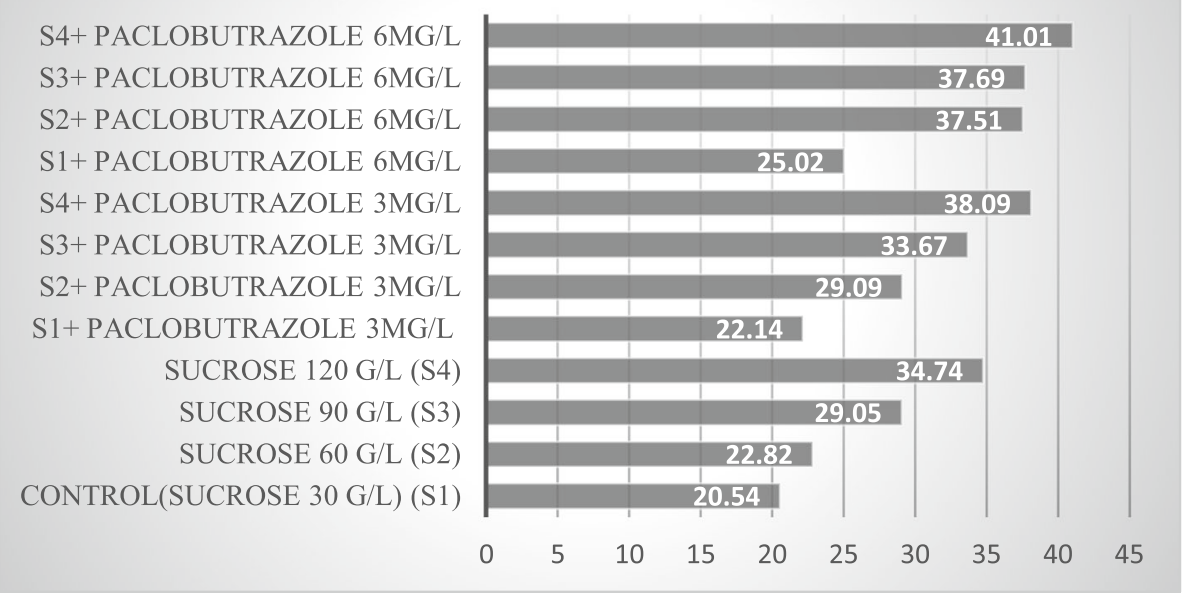

Fig. 6 Carbohydrates percent in Lilium bulblets with studied concentrations of sucrose and paclobutrazol 

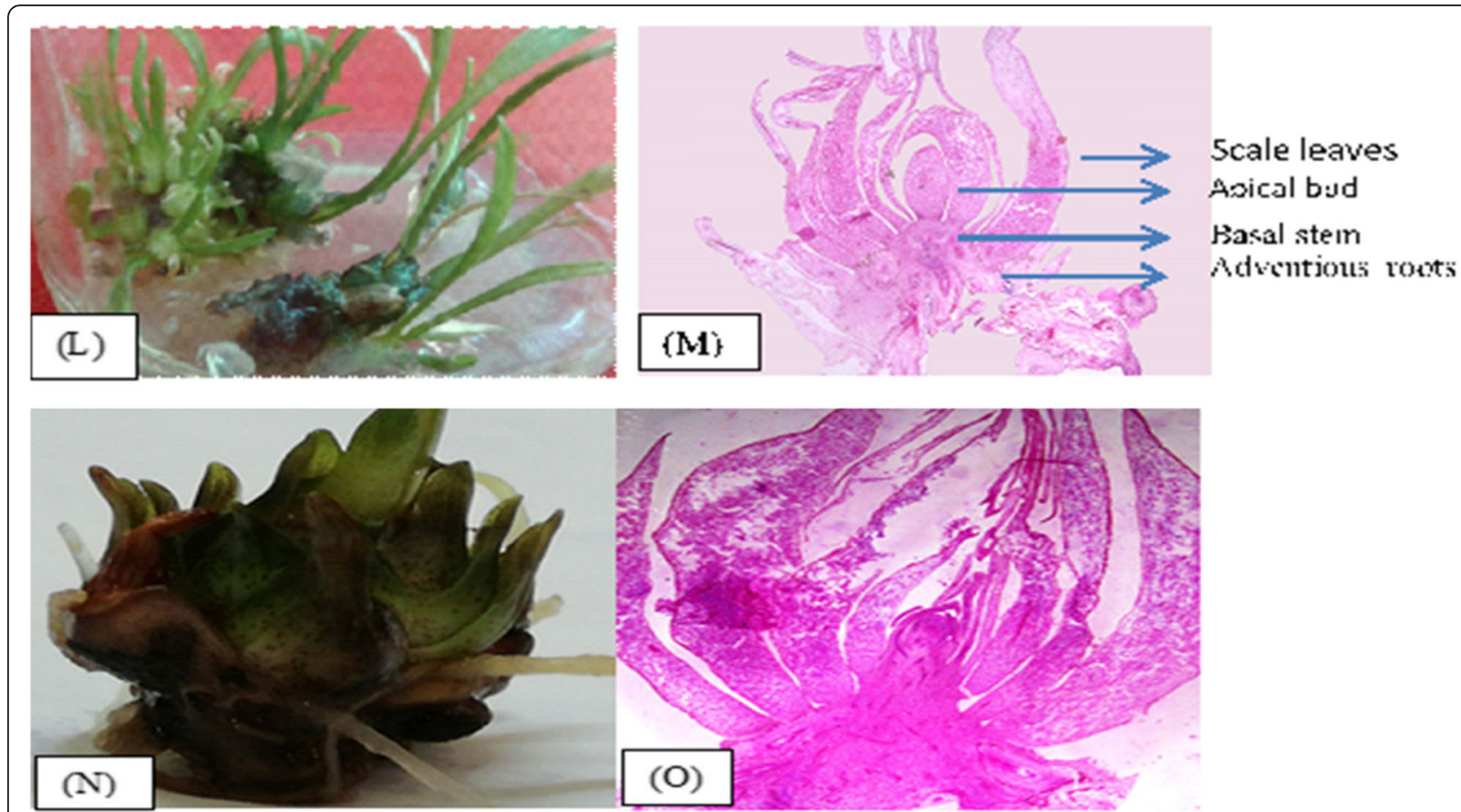

Fig. 7 Bulblet formation during the third subculture. I, $\mathbf{m}$ Bulblets formed on MS medium supplemented with $30 \mathrm{~g} / \mathrm{l}$ sucrose + BA $1.0+$ NAA0.2 mg/l (control). $\mathbf{n}$, o The acclimatized bulb from MS medium with $120 \mathrm{~g} / \mathrm{l}$ sucrose + paclobutrazol at $6 \mathrm{mg} / \mathrm{l}$ treatment.

(10 $\mathrm{mg} / \mathrm{l})$ and indirect micropropagation by MS supplemented with TDZ $(0.5 \mathrm{mg} / \mathrm{l})+2,4-\mathrm{D}(5 \mathrm{mg} / \mathrm{l})$ or using 2ip $(0.5 \mathrm{mg} / \mathrm{l})+$ picloram $(5 \mathrm{mg} / \mathrm{l})$. Using $60 \mathrm{~g} / \mathrm{l}$ of sucrose plus 3 or $6 \mathrm{mg} / \mathrm{l}$ of paclobutrazol led to the highest number of bulblets/explant. The highest bulblet diameters were recorded with $120 \mathrm{~g} / \mathrm{l}$ sucrose plus 6 or $3 \mathrm{mg} / \mathrm{l}$ paclobutrazol.

\section{Acknowledgements}

The authors are greatly thankful to the National Research Centre, $33 \mathrm{El}$ Bohouth st. (formal El Tahrir st.), Dokki, Giza, Egypt, P.O.12622, for providing the funding credit of this work through supporting project number 11030152.

\section{Authors' contributions}

NMY and LST performed the in vitro experiment, analyzed the data, and contributed in writing and reviewing the paper. SAS performed the anatomical study. ZFG performed a part of the in vitro experiment. All authors read and approved the final manuscript.

\section{Funding}

This work was supported and funded by the National Research Centre, project no. 11030152 under the title "Propagation of economic importance ornamental and woody plants using new applications" during 2016/2019.

\section{Availability of data and materials}

The datasets generated and/or analyzed during the current study are included in this published article.

\section{Ethics approval and consent to participate}

Not applicable

\section{Consent for publication}

Not applicable

\section{Competing interests}

The authors declare that they have no competing interests.

\section{Author details}

${ }^{1}$ Ornamental Plants and Woody Trees Dept., National Research Centre, P.O. Box 12622, Dokki, Giza, Egypt. ²Department of Agricultural Botany, Faculty of Agriculture, Cairo University, Giza, Egypt. ${ }^{3}$ Botanical Garden Research Dept, Horticulture Res. Inst., Agricultural Research Center, Giza, Egypt.

Received: 1 October 2019 Accepted: 3 December 2019

Published online: 30 December 2019

\section{References}

Bahr LR, Compton ME (2004) Competence for in vitro bulblet regeneration among eight Lilium genotypes. HortScience 39(1):127-129

Bakhshaie M, Babalar M, Mirmasoumi M, Khalighi A (2010) Effects of light, sucrose, and cytokinins on somatic embryogenesis in Lilium ledebourii (Baker) Bioss. via transverse thin cell-layer cultures of bulblet microscales. J Hortic Sci Biotechnol 85:491-496

Bonnier FJM, Van TJM (1997) Long term In vitro storage of lily: effect of temperature and concentration of nutrient and sucrose. Plant Cell Tiss Organ Cult 49:81-87

Coulston GH, Shearing SJ (1985) Review of the effects of paclobutrazol on ornamental pot plants. Acta Hortic 167:339-348

Dam ASP, Bandyopadhyay TK (2010) Direct somatic embryogenesis and plant regeneration from leaf explants of Limonium sinensis (Girard) Kuntze. Sci Hortic 126(2):253-260

Dubois M, Gilles KA, Hamilton JK, Rebers PA, Smith F (1956) Colorimetric method for determination of sugars and related substances. Anal Chem 28(3):350-356

Hazarika BN (2003) Acclimatization of tissue cultured plants. Curr Sci 85:1704-1712

Huetteman CA, Preece JE (1993) Thidiazuron: a potent cytokinin for woody plant tissue culture. Plant Cell Tissue Organ Cult 33:105-119

Joshi SK, Dhar U (2009) In vitro propagation from axenic explants of Lilium oxypetalum (D. Don) Baker, an endemic bulbous plant of high-altitude Himalaya. Acta Physiol Plant 31(4):833-838 
Kumar S, Kashyap M, Sharma DR (2005) In vitro regeneration and bulblet growth from lily bulbscale explants as affected by retardants, sucrose and irradiance. Biol Plant 49(4):629-632

Kumar S, Kanwar JK, Sharma DR (2006) In vitro propagation of Lilium. Adv Hortic Sci 20:181-188

Langens-Gerrits M, Lilien-Kipnis H, Croes T, Miller W, Kolloffel C, De Klerk GJ (1997) Bulb growth in lily regenerated in vitro. Acta Hortic 430:267-273

Langens-Gerrits MM, Kuijpers AM, De Klerk GJ, Croes A (2003) Contribution of explant carbohydrate reserves and sucrose in the medium to bulb growth of lily regenerated on scale segments in vitro. Physiol Plant 117:245-255

Lian M, Chakrabarty D, Paek KY (2002) Growth and uptake of sucrose and mineral ions by bulblets of Lilium oriental hybrid 'Casablanca' during bioreactor culture. J Hortic Sci Biotechnol 77(3):253-257

Lian ML, Murthy HN, Paek KY (2003) Photoautotrophic culture conditions and photosynthetic photon flux influence growth of Lilium bulblets in vitro. In Vitro Cell Dev Biol Plant 39(5):532-535

Muhanmmad N, Ishrat N, Syed MSN, Tariq M (2013) Standardization of tissue culture conditions and estimation of free scavenging activity in Viola odorata L. Pak J Bot 45(1):197-202

Murashige T, Skoog F (1962) A revised medium for rapid growth and bio assays with tobacco tissue cultures. Physiol Plant 15:473-496

Nagaraju V, Bhowmik G, Parthasarathy VA (2002) Effect of paclobutrazol and sucrose on in vitro cormel formation in gladiolus. Acta Bot Croat 61(1):27-33

Paek KY, Murthy HN (2002) High frequency of bulblet regeneration from bulb scale sections of Fritillaria thunbergii. Plant Cell Tiss Organ Cult 68(3):247-252

Pelkonen V (2005) Biotechnological approaches in lily (Lilium) production. University of Oulu, Oulu. Available from: http://herkules.oulu.fi/isbn9514276590/. ISBN 95142-7659-0 (PDF). ISSN 0355-3191 http://herkules.oulu.fi/issn03553191

Pobudkiewicz A, Treder J (2006) Effects of flurprimidol and daminozide on growth and flowering of oriental lily 'Mona Lisa'. Sci Hortic 110:328-333

Robinson KE, Firoozabady E (1993) Transformation of floriculture crops. Sci Hortic 55:83-99

Roh MS (2011) Controlled flowering in the genus Lilium-review of the past achievements and the future direction of research. Acta Hortic 900:189-203

Smith EF, Roberts AV, Mottley J (1990) The preparation in vitro of chrysanthemum for transplantation to soil. 2. Improved resistance to desiccation conferred by paclobutrazol. Plant Cell Tiss Organ Cult 21:133-140

Steel RGD, Torrie JH (1980) Principles and procedures of statistics, 2nd edn. McGraw-Hillbook Co., Inc., New York/Toronto/London. 633 p. isbn:0-07060926-8

Taha SL, Sayed SS, Farahat MM, El-Sayed IM (2018) In vitro culture and bulblets induction of Asiatic hybrid Lily 'red alert'. J Biol Sci 18:84-91

Thakur R, Sood A, Nagar PK, Pandey S, Sobti RC, Ahuja PS (2006) Regulation of growth of Lilium plantlets in liquid medium by application of paclobutrazo or ancymidol, for its amenability in a bioreactor system: growth parameters. Plant Cell Rep 25:382-391

Varshney A, Dhawan V, Srivastava PS (2000) A protocol for in vitro mass propagation of Asiatic hybrids of lily through liquid stationary culture. In Vitro Cell Dev Biol Plant 36(5):383-391

Vinterhalter B, Mitić N, Vinterhalter D, Uzelac B, Krstić-Milošević D (2016) Somatic embryogenesis and in vitro shoot propagation of Gentiana utriculosa. Biologia 71(2):139-148

Wang AQ, He LF, Zhou Q, Sheng YP (1999) Comparative study on transplanting of lily plantlets. J Guangxi Agric Biol Sci 18(3):187-189

Willey RL (1971) Microtechniques: a laboratory guide. Macmillan Publishing Co., Inc., New York 99 p. ISBN-10: 0024277908, ISBN-13: 978-0024277909

Wu Y, Sun M, Zhang J, Zhang Ren Z, Min R, Wang X, Xia Y (2019) Differential effects of paclobutrazol on the bulblet growth of oriental lily cultured in vitro: growth behavior, carbohydrate metabolism, and antioxidant capacity. J Plant Growth Regul 38:359-372

Yamagishi M (1998) Effects of culture temperature on the enlargement, sugar uptake, starch accumulation, and respiration of in vitro bulblets of Lilium japonicum Thunb. Sci Hortic 73:239-247

Younis A, Hwang YJ, Lim KB (2014) Classical vs. modern genetic and breeding approaches for lily (Lilium) crop improvement: a review. Flower Res J 22:39-47

Ziv M (1989) Enhanced shoot and cormlet proliferation in liquid cultured gladiolus buds by growth retardants. Plant Cell Tissue Organ Cult 17:101-110

\section{Publisher's Note}

Springer Nature remains neutral with regard to jurisdictional claims in published maps and institutional affiliations.

\section{Submit your manuscript to a SpringerOpen ${ }^{\odot}$ journal and benefit from:}

- Convenient online submission

- Rigorous peer review

- Open access: articles freely available online

High visibility within the field

- Retaining the copyright to your article

Submit your next manuscript at $\boldsymbol{\nabla}$ springeropen.com 